\title{
THE VALUE OF THE KAHN REACTION TWO FURTHER CASES
}

By D. KATHLEEN BROWN, M.B., B.S. ; L. W. CANN, M.B., B.S., D.P.H. ; S. DE NAVASQUEZ, M.B., B.S., D.T.M. \& H.

SINCE the publication of an article $^{1}$ on the relative values of the Kahn test and Wassermann reaction, two cases of interest have been selected for publication from those treated at the Female Venereal Diseases Clinic, Guy's Hospital. They both confirm in an emphatic manner the main conclusion in the above paper - that the Kahn test is a more sensitive index of syphilitic infection than the Wassermann reaction.

\section{Case i. Female. No. 4032}

A woman, aged 29 years, married, two children, first attended the Out-patient Annexe (Female) on February I8th, I931. She was referred by the Male Annexe, her husband having attended the previous day with a primary sore of seven days' duration (Wasserman strong positive $(++++)$ Kahn ++++$)$.

The patient did not complain of any symptoms. The last marital coitus took place three weeks previously, about two weeks before her husband noticed a sore.

On examination locally there was no sign of a primary sore and no enlargement of inguinal glands. The Wassermann and Kahn were both negative.

It was arranged that the patient should attend three times weekly for observation.

On February 23rd the anterior lip of the cervix appeared hyperæmic. There was not a definite erosion, but there was bleeding on touch with a pipette. Serum was collected, but no Treponema pallida were found on darkground illumination. On February 26th there was a typical erosion of the cervix. Serum was taken six times in all with negative results by dark-ground illumination.

On March I6th the Kahn was +, the Wassermann remaining negative. 


\section{THE VALUE OF THE KAHN REACTION}

Treatment-a course of N.A.B. and Bismostab concurrently-was started on March 24th. On this occasion and subsequently blood was taken for a Wassermann and Kahn before each injection of N.A.B. was given. The results of the tests are shown in tabular form.

\begin{tabular}{|c|c|c|c|}
\hline Date. & W.R. & Kahn. & Treatment, etc. \\
\hline $\begin{array}{rrr}\text { I8 } & 2 & 3 \mathrm{I} \\
\mathrm{I} 6 & 3 & 3 \mathrm{I} \\
24 & 3 & 3 \mathrm{I} \\
26 & 3 & 3 \mathrm{I} \\
3 \mathrm{I} & 3 & 3 \mathrm{I} \\
4 & 4 & 3 \mathrm{I} \\
\mathrm{II} & 4 & 3 \mathrm{I} \\
\mathrm{I} 8 & 4 & 3 \mathrm{I} \\
24 & 4 & 3 \mathrm{I} \\
7 & 5 & 3 \mathrm{I} \\
22 & 6 & 2 \mathrm{I}\end{array}$ & $\begin{array}{l}- \\
- \\
- \\
- \\
- \\
- \\
-\end{array}$ & $\begin{array}{c}- \\
+ \\
++ \\
+++ \\
++ \\
++++ \\
++ \\
+ \\
+ \\
-\end{array}$ & $\begin{array}{l}\text { N.A.B. } \cdot \text { I } 5 \mathrm{gm} . \\
\text { N.A.B. } \cdot 3 \mathrm{gm} . \\
\text { Bismostab I c.c. } \\
\text { N.A.B. } \cdot 45 \mathrm{gm} . \\
\text { N.A.B. } \cdot 45 \mathrm{gm} . \text { Bismo. I c.c. } \\
\text { N.A.B. } \cdot 45 \mathrm{gm} . \text { Bismo. I c.c. } \\
\text { N.A.B. } \cdot 6 \mathrm{gm} . \text { Bismo. I c.c. } \\
\text { N.A.B. } \cdot 6 \mathrm{gm} . \text { Bismo. I c.c. } \\
\text { N.A.B. } \cdot 6 \mathrm{gm} . \text { Bismo. I c.c. }\end{array}$ \\
\hline
\end{tabular}

The diagnosis of syphilis was never established either by typical clinical lesions nor by the detection of Treponema pallida. Nevertheless, the almost symmetrical rise of the Kahn readings to a full positive and the steady decline following anti-syphilitic treatment when considered with the case history make the diagnosis extremely probable.

\section{Case 2. Female. No. 4I 24}

The patient, aged 20 years, single, first attended on April I4th, I93I. She was referred by the Male Annexe, her fiancé having attended with a primary sore of fourteen days' duration (Wassermann positive $(+), \mathrm{Kahn}++++$ on February 9th).

The patient complained of local " soreness and chafing "for one month. The last coitus took place ten or twelve weeks previously.

On examination there was an indurated fissure at the fourchette with surrounding hyperæmia and enlargement of the inguinal glands. The throat was injected, but not ulcerated. There were also a few macules on the trunk which were very suggestive of an early secondary rash.

Serum was taken from the primary sore, but the result was negative. A second examination was made on the following day, April I5th, and Treponema pallida were 


\section{BRITISH JOURNAL OF VENEREAL DISEASES}

found. The Wassermann was negative and the Kahn ++++ . Further results of blood tests are shown in the table below.

Injections of N.A.B. and Bismostab were given concurrently. The primary sore healed in one week and there was no further development of the rash.

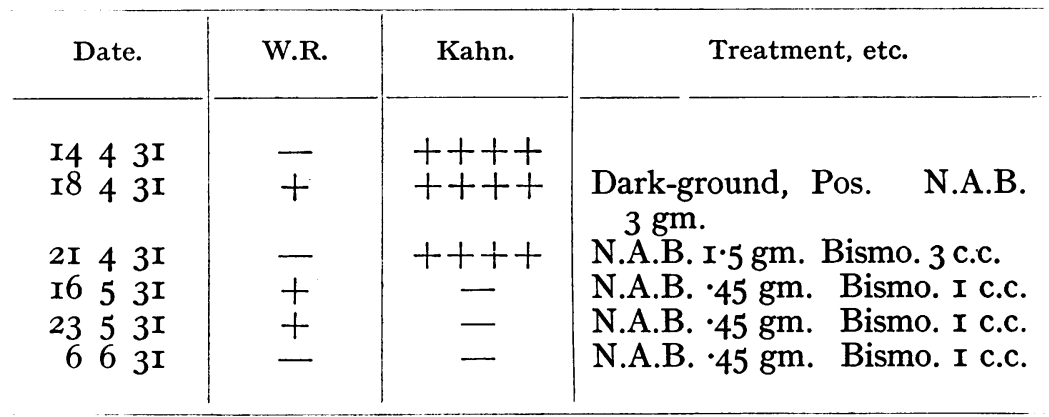

A secondary peculiarity about this case is the appearance of a delayed positive Wassermann reaction which occurred for a short period after the Kahn had become negative.

We would point out that in selecting these two cases we have not suppressed other cases which would show a similar discrepancy in favour of the Wassermann.

Our investigations have, as yet, failed to disclose such cases.

We wish to express our thanks to Mr. V. E. Lloyd and Miss M. Rawlins for access to the case records.

\section{REFERENCE}

I (I) Cann, L. W. and De Navasquez, S. (I93I), Brit. J. Vener. Dis., vii., No. 2, p. 105. 